\title{
FETAL BRAIN DAMAGE IN HUMAN FETUSES WITH CONGENITAL CYTOMEGALOVIRUS INFECTION: HISTOLOGICAL FEATURES AND VIRAL TROPISM
}

\section{Liliana Gabrielli ( $\sim$ liliana.gabrielli@aosp.bo.it )}

Microbiology Unit, IRCCS, S.Orsola Polyclinic, Bologna https://orcid.org/0000-0002-5994-4749

\section{Piccirilli Giulia}

Microbiology Unit, IRCCS S.Orsola Polyclinic, Bologna

\section{Gabrielli Liliana}

Microbiology Unit, IRCCS S.Orsola Polyclinic, Bologna

\section{Bonasoni Maria Paola}

Operative Unit of Pathology, IRCCS Santa Maria Hospital, Reggio Emilia

\section{Chiereghin Angela}

Section of Microbiology, Department of Specialized, Experimental and Diagnostic Medicine, University of Bologna and Department of Public Health, Local Authority of Bologn, Bologna

\section{Turello Gabriele}

Microbiology Unit, Department od Specialized, Experimental and Diagnostic Medicine, University of Bologna, IRCCS S.Orsola Polyclinic, Bologna

\section{Borgatti Eva Caterina}

Microbiology Unit, Department of Specialized, Experimental and Diagnostic Medicine, University of Bologna, IRCCS S.Orsola Polyclinic, Bologna

\section{Simonazzi Giuliana}

Department of Obstetrics and Gynecology, IRCCS S.Orsola Polyclinic, Bologna

\section{Felici Silvia}

Microbiology Unit, Department of Specialized, Experimental and Diagnostic Medicine, University of Bologna, IRCCS S.Orsola Polyclinic, Bologna

\section{Leone Marta}

Microbiology Unit, Department of Specialized, Experimental and Diagnostic Medicine, University of Bologna, IRCCS S.Orsola Polyclinic, Bologna

\section{Salfi Nunzio Cosimo Mario}

Pathology Unit, IRCCS Giannina Gaslini Institute, Genova

\section{Santini Donatella}

Pathology Unit, IRCCS S. Orsola Polyclinc, Bologna

\section{Lazzarotto Tiziana}

Microbiology Unit, Department of Specialized, Experimental and Diagnostic Medicine, University of Bologna, IRCCS S.Orsola Polyclinic, Bologna 


\section{Research Article}

Keywords: Cytomegalovirus, brain damage, congenital infection, fetus, viral tropism, neural cells, hippocampus

Posted Date: February 7th, 2022

DOI: https://doi.org/10.21203/rs.3.rs-1303512/v1

License: (1) (1) This work is licensed under a Creative Commons Attribution 4.0 International License. Read Full License 


\section{Abstract}

Human cytomegalovirus (HCMV) causes congenital neurological lifelong disabilities. To date, the neuropathogenesis of brain injury related to congenital HCMV (cCMV) infection is poorly understood. This study evaluates the characteristics and pathogenetic mechanisms of encephalic damage in CCMV infection.

Ten HCMV-infected human fetuses at 21 weeks of gestation were examined. Specifically, tissues from different brain areas were analyzed by: $i)$ immunohistochemistry (IHC) to detect HCMV-infected cell distribution, ii) hematoxylin-eosin staining to evaluate histological damage and iii) real-time PCR to quantify tissue viral load (HCMV-DNA). The differentiation stage of HCMV-infected neural/neuronal cells was assessed by double IHC to detect simultaneously HCMV-antigens and neural/neuronal markers: nestin (expressed in early differentiation stage), doublecortin (DCX, identifying neural cells with determined lineage) and neuronal nuclei (NeuN, identifying mature neurons).

HCMV-positive cells and viral DNA were found in the brain of $8 / 10(80 \%)$ fetuses. For these cases, brain damage was classified as mild $(n=4,50 \%)$, moderate $(n=3,37.5 \%)$ and severe $(n=1,12.5 \%)$ based on presence and frequency of pathological findings (necrosis, microglial nodules, microglial activation, astrocytosis and vascular changes). The highest median HCMV-DNA level was found in the hippocampus (212 copies/5ng of humanDNA [hDNA], range: 10-7,505) as well as the highest mean HCMV-infected cell value (2.9 cells, range: $0-23$ ), followed by that detected in subventricular zone (1.8 cells, range: $0-19)$. This suggested a preferential viral tropism for neural stem/progenitor cells (NSPCs), residing in these regions, confirmed by the expression of DCX and nestin in $94 \%$ and $63.3 \%$ of HCMV-positive cells, respectively. NeuN was not found among HCMV-positive cells and was nearly absent in the brain with severe damage, suggesting HCMV does not infect mature neurons and NSPCs do not differentiate into neurons. This could lead to known structural and functional brain defects from cCMV infection.

\section{Introduction}

Human cytomegalovirus (HCMV) is the most frequent congenital virus infection worldwide, with an incidence of approximately $0.64 \%$ live births (Mack et al. 2017; Rawlinson et al. 2017). Although congenital HCMV (CCMV) infection may involve many fetal organs, the most significant injuries are those related to lesions in the nervous system that are irreversible and persist for life Fowler at al. 2003; Gabrielli et al. 2009; Kenneson and Cannon 2007). Permanent neurological damage occurs in up to $60-70 \%$ of newborns symptomatic at birth (10\% of congenitally infected cases) and in the $10-15 \%$ of those asymptomatic (Cheeran at al.2009; Gaytant at al. 2002). Neurological outcomes may include sensorineural hearing loss, visual impairments, microcephaly, encephalic palsy, mental retardation, epilepsy and seizure (Boppana at al.2013; Cheeran at al.2009;Gaytant at al. 2002; Schleiss 2008; Zhang and Fang 2019). Clinical conditions involving the central nervous system (CNS) are mainly the result of intracranial calcifications, periventricular cysts, white matter abnormalities, intraventricular adhesions, ventriculomegaly, altered sulcation/gyral patterns and cerebellar abnormalities (Fink at al. 2010; Kwak at 
al. 2018; Malinger at al. 2003).To date, the pathogenesis of injury in the developing fetal brain related to cCMV infection is poorly understood (Gaytant at al. 2002; Schleiss 2008). Results obtained by previous studies, involving HCMV infected human fetuses, showed that it could be due to a multifactorial process including the effects in the brain of direct viral replication, inflammatory and immune response to infection as well as the encephalic hypoxic ischemia secondary to HCMV-related placental damage (Gabrielli at al. 2009, 2012). The development of the CNS is a complex process that includes proliferation and differentiation ofneural stem/progenitor cell (NSPCs), neuronal migration, neurite outgrowth, and synapse formation (Zhang and Fang 2019). Viral replication could have a key role in neuropathogenesis of HCMV-induced brain injury interfering with these developmental stages. Studies, mainly performed on cultured murine and human brain cells, indicate that CNS infected cells have altered intercellular communication, deficient response to neurotransmitters and cell cycle changes (Cheeran at al. 2009; Ho and van den Pol 2007; Lokensgard et al. 1999; Schleiss 2008). In addition, Tsutsui $Y$ et al. showed a preferential tropism of murine cytomegalovirus (MCMV) for the immature and proliferating neural cells (Tsutsui at al. 2002, 2005). These findings could also implicate a specific brain localization of viral infection, as well as those described for other herpes viruses, such as the herpes simplex virus-1 (HSV-1), for which temporal lobe abnormalities are commonly reported in patients with herpes simplex encephalitis (Levitz 1998; Mook-Kanamori at al. 2009). All these findings were poorly investigated in human cases of cCMV infection.

The present study aimed to implement the knowledge on histological characteristics of HCMV-induced encephalic injury and the mechanism by which the direct viral replication lead to neurological disorders. To our knowledge, this is the first study that analyzed human brain tissues from fetuses with cCMV infection to define in different encephalic areas the distribution of; i) histological features, ii) HCMVinfected cells and iii) tissue viral load. In addition, the differentiation stage of infected neural/neuronal cells was evaluated to clarify how HCMV infection could interfere with fetal brain development.

\section{Material And Methods}

\section{Study design and patients}

All congenitally HCMV infected fetuses submitted for histological examination at Pathology Unit, IRCCS S. Orsola Polyclinic from 2010 to 2019 were revised. We selected all fetuses with the same features: mothers with primary HCMV infection occurring before twelve weeks of gestation (WG), high viral load in amniotic fluid, elective termination of pregnancy at $21 \mathrm{WG}$, all brain regions with available paraffin-embedded blocks. Ten fetuses met these inclusion criteria. In table 1, maternal clinical information at the time of primary HCMV infection are summarized.

Table 1 Maternal clinical information at the time of serological diagnosis of primary HCMV infection. 


\begin{tabular}{|c|c|c|c|c|c|}
\hline $\begin{array}{l}\text { Case } \\
\text { No. }\end{array}$ & $\begin{array}{l}\text { Age } \\
\text { (years) }\end{array}$ & $\begin{array}{l}\text { Serological diagnosis } \\
\text { of primary } \\
\text { CMV infection }\end{array}$ & $\begin{array}{l}\text { WG } \\
\text { atdiagnosis }\end{array}$ & Symptoms & Laboratory findings \\
\hline 9 & 33 & IgGseroconversion & 11 & - & Lymphocytosis \\
\hline \multirow[t]{2}{*}{1} & 29 & $\begin{array}{l}\lg M \text { antibodies and low } \\
\lg G\end{array}$ & 9 & - & - \\
\hline & & avidity & & & \\
\hline 2 & 25 & $\begin{array}{l}\text { IgM antibodies and low } \\
\text { lgG avidity }\end{array}$ & 12 & $\begin{array}{l}\text { Influenza-like } \\
\text { syndrome }\end{array}$ & $\begin{array}{l}\text { Lymphocytosis and } \\
\text { abnormal liver } \\
\text { enzyme levels }\end{array}$ \\
\hline 7 & 35 & $\begin{array}{l}\text { IgM antibodies and low } \\
\text { IgG avidity }\end{array}$ & 10 & Fever & $\begin{array}{l}\text { Abnormalliver } \\
\text { enzyme levels }\end{array}$ \\
\hline 3 & 37 & $\begin{array}{l}\text { IgM antibodies and low } \\
\text { IgG avidity }\end{array}$ & 8 & - & - \\
\hline 4 & 19 & $\begin{array}{l}\text { IgM antibodies and low } \\
\text { IgG avidity }\end{array}$ & 10 & Asthenia & $\begin{array}{l}\text { Abnormalliver } \\
\text { enzyme levels }\end{array}$ \\
\hline 5 & 22 & IgGseroconversion & 11 & - & - \\
\hline 8 & 33 & $\begin{array}{l}\text { IgM antibodies and low } \\
\text { IgG avidity }\end{array}$ & 11 & Fever & - \\
\hline 6 & 32 & IgGseroconversion & 9 & - & - \\
\hline 10 & 39 & $\begin{array}{l}\text { IgM antibodies and low } \\
\lg G\end{array}$ & 10 & - & - \\
\hline & & avidity & & & \\
\hline
\end{tabular}

WG: weeks of gestation; :- none

As control cases, seven fetuses at 21-weeks of gestation from HCMV seronegative women were also studied. Three were from a termination of pregnancy due to fetal cardiac malformation and the other four were spontaneous miscarriages caused by cervical incompetence. A total of 17 fetuses were analyzed and for each one, 10 brain regions were selected. In particular, tissues from the cortical areas (frontal, temporal, occipital, parietal) and underlying white matter, subventricular zone, thalamus, hypothalamus, hippocampus, basal ganglia and cerebellum were analyzed. All encephalic areas were examined by i) immunohistochemical staining to detect the presence and distribution of brain cells expressing HCMVantigens; ii) hematoxylin-eosin staining to evaluate the histological damage in HCMV positive brain; and iii) real-time PCR to detect and quantify the tissue viral load. Double immunohistochemical staining for simultaneous detection of HCMV-antigens with markers identifying the differentiation stage of infected neural/neuronal cells, was performed. All analyses were carried out on sections obtained from paraffinembedded blocks of tissue previously fixed in $4 \%$ formaldehyde. 
Regarding histological analysis, a positive and a negative standardized sample were included for each immunohistochemical session in order to confirm the required sensibility and specificity of the antibodies used. In particular, tissues that did not express the target protein were used to confirm antibody specificity to the protein of interest.

All the histological slides were analyzed by two independent observers blind to virological results. Discordant results were resolved by a third observer.

The study was approved by the Ethical Committee of St. Orsola Polyclinic, University Hospital, Bologna, Italy (approval numbers: 14/2017/U/tess and 8/2010/O/Sper). The fetal tissues were analyzed after receiving informed consent from the parents prior to inclusion, according to the policies of the Ethical Committee and to the regulation of the Italian Ministry of Health.

\section{Histological brain damage evaluation in HCMV-positive brain}

One section of 3 microns/brain area was analyzed by hematoxylin-eosin staining, performed by standard method. The presence of necrosis, microglial nodules, microglial activation, astrocytosis, and vascular changes was evaluated. Microglial nodules consisted in clusters of activated microglial cells involved in immune response to HCMV-infected cells. Microglial activation was proved by microglial body cells with various morphologies: small rod-shape, amoeboid-like and spherical cells. Astrocytosis was characterized by cell body expansion (hypertrophy) and cells with clear nuclei (named Alzheimer type II cells). Vascular changes consisted in increased number of vessels with hypertrophy of endothelial cells (that showed plump, cuboidal form and protruded into the lumen).

Considering the severity and the frequency of pathological findings, the brain damage was classified as i) severe, in presence of tissue necrosis and multiple microglial nodules ( $\geq 3 /$ brain region); ii) moderate, in presence of multiple microglial nodules without necrosis and iii) mild, in presence of occasional microglial nodules (<3/brain region) without necrosis. In all brain regions, 5 fields at 20 high-power field (HPF), were evaluated (Gabrielli et al. 2012).

\section{Detection and quantification of brain tissue viral load}

Each selected brain area was anatomically identified, dissected from 2 sections of 8 microns and placed in a $1.5 \mathrm{~mL}$ tube for the deparaffinization procedure using $160 \mu \mathrm{L}$ of the Deparaffinization Solution(product code: 19093; Qiagen, Germany). DNA extraction was performed by the QIAsymphony ${ }^{\circledR} S P$ instrument with the QIAsymphony DSP DNA Mini Kit (product code: 937236; Qiagen, Germany). Purified DNA was eluted in $50 \mu \mathrm{L}$ and the contained human DNA (hDNA) was quantified using a real-time PCR assay, Quantifiler ${ }^{\circledR}$ Human DNA Quantification Kit (product code: 4343895; Life Technologies, USA). Five nanograms of hDNA were processed for HCMV-DNA quantification, carried out using a real-time PCR assay, CMV ELITe MGB ${ }^{\text {TM }}$ kit (product code: RTK015PLD; ELITech Group, Italy). The tissue viral load was reported as number of copies/5ng of hDNA. The lower limit of quantification (LLoQ) was equal to 13 copies/ $5 \mathrm{ng}$ of hDNA. Positive results below the LLoQ were censored with a value equal to 10 copies/5ng hDNA (Gabrielli et al. 2017). 


\section{Detection and distribution of HCMV- infected brain cells}

One section of 3 microns/brain area was analyzed by immunohistochemical staining, performed using anti-CMV [8B1.2, 1G5.2, 2D 4.2] mouse monoclonal primary antibody (product code: 213M-26; Cell Marque, USA), that reacts with immediate early, delayed early, and late HCMV-antigen preparation. The HCMVinfected cells distribution in the brain was assessed analyzing 5 fields/brain regions at $10 \mathrm{HPF}$. The results were expressed as mean of HCMV-positive cells/encephalic area (Gabrielli et al. 2019 and 2020).

\section{Differentiation stage of the HCMV-infected neural/neuronal cells}

Serial sections of 3 microns/brain area were analyzed by double immunohistochemical staining for simultaneously detection of HCMV-antigens with markers of neural/neuronal cells. In particular, nestin was used as a marker to recognize cells in the early stage of differentiation, DCX was used to identify neural cells with lineage determined and NeuN for mature neurons detection. The first immunohistochemical reaction was the anti-HCMV staining (pre-diluted mouse monoclonal anti-CMV, clone 8B1.2 1G5.2\&2D4.2, Cell Marque USA), visualized using the OptiView DAB detection kit (brown color), followed by the second antibody represented by monoclonal anti-nestin clone 10c2 (product code: SC23927; Santa Cruz Biotech, USA) diluted 1:400, monoclonal anti-DCX clone 2 G5 (product code: MABN707; Millipore USA) diluted 1:600 or polyclonal anti-NeuN(product code: ab128886; Abcam Ltd, UK) diluted 1:300. The second immunoreaction was visualized using the Alkaline phosphatase UltraView detection Kit (product code: 760-501; red color). The double-labelled cells were assessed by analyzing 5 fields/brain regions at $10 \mathrm{HPF}$ (Chen et al. 2010).

\section{Statistical analysis}

The Mann-Whitney test was used to compare the HCMV-DNA levels detected in severe and moderate brain damage versus mild brain damage cases.The differences in HCMV DNA levels and HCMV-infected cells of each brain regions were analyzed with Kruskal-Wallis test and One-Way ANOVA test, respectively.The mean values of HCMV-infected cells found in severe and moderate brain damage were compared with those detected in mild brain damage cases by independentt-test.

\section{Results}

HCMV-positive cells and HCMV-DNA were found in the brain of 8/10 (80\%) fetuses. These results together with the data obtained by invasive (detection of HCMV-DNA in amniotic fluid) and non-invasive (ultrasound examination) prenatal diagnosis, performed at 21 WG, are reported in Table 2. For the subsequent examinations, the attention was focused on the cases with an encephalic involvement of HCMV infection. In the remaining 2 fetuses, no HCMV-positive cells and no viral DNA in the brain were observed. In control cases, no HCMV-positive cells and HCMV-DNA were detected in the brain.

\section{Detection of pathological findings and evaluation of brain injury}


Microglial activation, diffuse astrocytosis and vascular changes were detected in all 8 cases (Fig. 1), without differences in the brain region distribution. These evidences showed a diffuse encephalic inflammatory reaction. However, as previously reported, considering the severity and the frequency of some histological encephalic abnormalities, such as necrosis and microglial nodules (Fig. 1), a different degree of brain injury was identified. The brain damage was classified as severe, moderate and mild in 1 (12.5\%), $3(37.5 \%)$ and $4(50 \%)$ cases, respectively (Table 2$)$. In particular, the brain with severe damage showed cortical necrosis, mainly detected in layer III, diffuse macrophage infiltration of the leptomeninges, polymicrogyria and periventricular leukomalacia. For the same case the cerebellum showed an extensive parenchymal hemorrhage with scarce residual tissue identified. In all cases with severe/moderate encephalic damage, viral load higher than $>10^{6} \mathrm{copies} / \mathrm{ml}$ in amniotic fluid were found, and the $50 \%$ of these cases showed pathological findings involving the brain via ultrasound (Table 2).

Table 2 Results of prenatal diagnosis performed at 21 WG in correlation with histological and virological brain findings.

\begin{tabular}{|c|c|c|c|c|c|c|}
\hline \multirow{3}{*}{$\begin{array}{l}\text { Case } \\
\text { No. }\end{array}$} & \multicolumn{3}{|c|}{ Prenatal diagnosis at 21 WG } & \multirow{2}{*}{\multicolumn{3}{|c|}{$\begin{array}{l}\text { Autopsy } \\
\text { Brain tissue }\end{array}$}} \\
\hline & \multirow{2}{*}{$\begin{array}{l}\text { HCMV-DNA } \\
\text { in AF } \\
\text { (copies/mL) }\end{array}$} & \multicolumn{2}{|l|}{ Ultrasound findings } & & & \\
\hline & & Brain & Other organs & $\begin{array}{l}\text { HCMV- } \\
\text { IHC }\end{array}$ & $\begin{array}{l}\text { HCMV- } \\
\text { DNA }\end{array}$ & Damage \\
\hline 9 & $>1,250,000$ & $\begin{array}{l}\text { Periventricular } \\
\text { hyperechogenicity }\end{array}$ & $\begin{array}{l}\text { Hyperechogenic } \\
\text { bowel }\end{array}$ & Positive & Positive & Severe \\
\hline 1 & $>1,250,000$ & $\begin{array}{l}\text { Periventricular } \\
\text { hyperechogenicity } \\
\text { Corpus } \\
\text { callosum hypoplasia }\end{array}$ & $\begin{array}{l}\text { Hyperechogenic } \\
\text { bowel }\end{array}$ & Positive & Positive & Moderate \\
\hline 2 & $>1,250,000$ & Normal & Normal & Positive & Positive & Moderate \\
\hline 7 & $>1,250,000$ & Normal & Normal & Positive & Positive & Moderate \\
\hline 3 & 182,000 & Normal & Normal & Positive & Positive & Mild \\
\hline 4 & $>1,250,000$ & Normal & Normal & Positive & Positive & Mild \\
\hline 5 & 948,473 & Normal & Normal & Positive & Positive & Mild \\
\hline 8 & 489,000 & Normal & Normal & Positive & Positive & Mild \\
\hline 6 & 323,300 & Normal & Normal & Negative & Negative & / \\
\hline 10 & 270,000 & Normal & Normal & Negative & Negative & / \\
\hline
\end{tabular}


IHC: Immunohistochemistry, /: not evaluated; AF: amniotic fluid; WG: weeks of gestation

\section{Quantification and distribution of tissue viral load into the brain}

The median HCMV-DNA levels detected in the brain of cases with severe and moderate damage were higher than those with mild encephalic injury: 92 copies/5ng hDNA (range: 20-380 copies/5ng hDNA) and 87 copies/5ng hDNA (range: 100-7,505 copies/5ng hDNA) versus 10 copies (range: 10-248 copies/5ng $h D N A)$, respectively $(Z=4.827, p<0.0001)$. The median level of tissue viral load in each brain area was different $(H=13.795 p=0.08)$ and the highest viral load, equal to 212 copies/5ng hDNA (range 10-7,505 copies/5ng hDNA), was detected in the hippocampus (Fig. 2).

Stratifying the median HCMV-DNA levels in correlation with the degree of brain damage, the highest values were also identified in the hippocampus. Values equal to 380 copies/5ng hDNA, 910 copies/5ng hDNA (range 105-7,505 copies/5ng hDNA) and 93 copies/5ng hDNA (range 10-248 copies/5ng hDNA) were detected in the cases with severe, moderate and mild brain damage, respectively (data not shown). Tissue viral load in severe brain damage was referred to the only case available. In addition, in this case, the HCMV-DNA values found in the cerebellum may be biased because it was severely hemorrhagic.

\section{Quantification and distribution of HCMV-positive cells into the brain}

HCMV-positive cells, including neural/neuronal, glial and endothelial cells were present as both scattered and grouped together in clusters. The HCMV-infected cells were also detected along the migration pathway probably affecting radial glia (Fig. 3).

The mean values of HCMV-positive cells, counted in each field over the different brain regions, in the cases with severe and moderate encephalic injury were higher than those found in the fetuses with mild brain damage: 2.49 cells (range: $0-9$ cells) and 1.57 cells (range: $0-23$ cells) versus 0.22 cells (range: $0-11$ cells), respectively ( $t=8.443 p<0.00001)$. The mean value of HCMV-infected cells in each brain area was different $(F=2.311, p=0.02)$ and the highest value was found in the hippocampus with 2.9 cells (range: 0 23 cells) followed by subventricular zone (including the periventricular areas in each lobe and the ganglionic eminence), with 1.8 cells (range: $0-19$ cells), Fig. 4. In addition, the mean values of HCMVpositive cells detected in the germinal matrix were higher than those observed in the cortical area and in white matter ( 3.5 cells in germinal matrix [range 0-19 cells], 0.8 cells in white matter [range: 0-7 cells] and 0.5 cells in cortex [range: $0-4$ cells]). In particular, this was observed in each brain lobe with the highest value in the germinal matrix of temporal lobe (data not shown).

\section{Differentiation stage of the HCMV-infected neural/neuronal cells}

The differentiation stage of HCMV-infected neural/neuronal cells was evaluated in 6 out of the 8 fetuses with HCMV-positive cells in the brain (cases in Table 2: 1,2,5,7,8,9).

The double immunohistochemical staining for simultaneous detection of HCMV-antigens and neural/neuronal cell markers showed that the $63.3 \%$ of HCMV-infected cells expressed nestin (441 nestin- 
HCMV-positive cells/696 HCMV-positive cells) and 94\% expressed DCX (601 DCX-HCMV-positive cells/639 HCMV-positive cells) (Fig. 5). In all cases, nestin used as marker of neural cells in early stage of differentiation, was mainly expressed in the subventricular zone and hippocampus, while in the white matter and cortex was weakly detected. In thalamus, hypothalamus and basal ganglia, this marker was not expressed. However, the positive cells for both HCMV-antigens and nestin were found in all brain regions, including the area where nestin was not usually expressed by non-infected neural cells (Fig. $5 b)$. Considering the results obtained using DCX as marker of neuronal progenitor cells with determined lineage, almost all HCMV-positive cells (94\%) expressed this marker. In the brain of the fetuses studied, DCX was diffusely expressed in each region, furthermore, positive-cells for both HCMV-antigens and DCX were detected in all encephalic areas. Finally, no HCMV-positive cells expressing NeuN were found (Fig. 5d). This marker, used to identify mature neurons, were mainly detected in the cortex, it was less expressed in white matter and was not found in the subventricular zone and hippocampus of studied cases.

When comparing the same brain region for fetuses with different degree of brain damage, in the case with severe encephalic injury, the expression of NeuN resulted almost absent compared to fetuses with moderate or mild brain damage (Fig. 6).

In the brain of control cases, no pathological findings were found. The nestin was mainly expressed in the hippocampus and the subventricular zone, weakly expressed in the white matter and cortical area and was absent in the thalamus, hypothalamus and basal ganglia (Fig. 7). DCX was diffusely found in all brain regions. NeuN was mainly detected in the cortical area, less expressed in white matter, thalamus and hypothalamus and almost absent in the subventricular zone and in the hippocampus.

\section{Discussion}

Although cCMV infection is the leading cause of significant damage in brain development, little is known about the neuropathogenic mechanisms by which this viral infection leads to human fetal cerebral injury (Cheeran at al. 2009). The results obtained by this study show encephalic viral infection in $80 \%(8 / 10)$ of examined fetuses, proved by the detection of HCMV-positive cells and HCMV-DNA in the brain. This suggests that not all HCMV-infected fetuses show cerebral involvement of viral replication, as reported in previous studies (Gabrielli at al. 2009, 2012, 2013).

In this study, we focused on the 8 cases with HCMV-positive cells and HCMV-DNA detected in the brain. The presence of diffused microglial activation, astrocytosis, and vascular changes observed in all brain regions, suggest a disseminate inflammatory response (Cotran and Pober 1989; Fernández-Arjonaat al. 2017; Robillard at al. 2016). In addition, microglial nodules in the same areas analyzed were also found. These lesions are a neuropathological characteristic of viral CNS infections, especially encephalitis caused by HSV-1 and HCMV. These were the result of microglial cells involved in phagocytosis of infected brain cells killed by CD8+ cytotoxic T-lymphocytes (Chen at al. 2019; Langford at al. 2002; Ludlow at al. 2016; Nebuloni at al. 2000; Rock at al. 2004; Tröscher at al. 2019).In a previous study, characterizing the 
encephalic inflammatory infiltrate in human fetuses with CCMV infection, the presence of microglial nodules containing HCMV-positive cells surrounded by activated CD8+ T-cells was demonstrated (Gabrielli et al. 2012). Except for necrosis, all pathological findings were not localized in specific brain areas, but uniformly distributed, probably due to diffuse inflammatory reaction and immune responses into the encephalon. The necrosis, found in the brain with severe damage and mainly localized in cortical layer III, could be due not only to direct viral replication, but also to hypoxia caused by HCMV-induced placental injury (Gabrielli et al. 2012). In the studied cases, the different degree of encephalic injury was classified as severe (12.5\%), moderate (37.5\%) and mild (50\%). In cases with severe/moderate brain damage, prenatal diagnosis performed at $21 \mathrm{WG}$, showed a high viral load in amniotic fluid (values more than $10^{6}$ copies $/ \mathrm{mL}$ ) and in $50 \%$ of cases, brain pathological findings detected by ultrasound examination. These findings are in agreement with published data reporting that the presence of high viral loads in amniotic fluid, sampled at the appropriate time, combined with ultrasound evidence of abnormalities in the CNS, are highly suggestive of fetal CCMV infection with poor outcome (Guerra at al. 2008; Lazzarotto at al. 2014; Pass and Arav-Boger 2018). In addition, in cases with severe/moderate encephalic damage, higher median HCMV-DNA values and mean values of HCMV-positive cells were found compared to those detected in cases with mild brain injury. This confirms a correlation between the degree of damage and the level of viral replication, as already reported (Gabrielli et al. 2012). Among brain areas, the highest viral load was identified in the hippocampus (median value 212 copies/5ng hDNA, range: 10-7,505 copies/5ng hDNA) as well as the highest HCMV-infected cells (mean value 2.9 cells, range: $0-23$ cells), followed by subventricular zone (1.8 cells, range: $0-19$ ). In addition, considering each cerebral lobe, the highest mean value of HCMV-positive cells was detected in the germinal matrix (part of subventricular zone) with respect to cortex and white matter. In acute encephalitis due to other neurotropic viruses, such as HSV-1, involvement of select brain regions are reported, including the limbic structure where the hippocampus is a susceptible target of infection (Damasio and Van Hoesen 1985; Harris and Harris 2018; Kopp at al. 2009; Lathe and Haas 2017; Potel et al. 2003). For HCMV infection, the main viral localization in the hippocampus (dentate gyrus) and cerebral subventricular zone was proven in few studies involving human subjects, such as adult immunocompromised patients and premature infants with lethal cCMV infection (Perlman and Argyle 1992; Yoon at al. 2017).Yin X et al., observed that during human fetal life, the highest proportion of NSPCs reside in the hippocampus, followed by the amount of these cells detected in subventricular zone (Yin at al. 2013). Considering these findings, though identified in a low number of fetuses studied, the highest viral load detected in hippocampus and the higher HCMV-infected cell values found in both hippocampus and in subventricular zone could probably suggest a preferential HCMV replication in the cerebral areas where NSPCs reside. Murine models of MCMV infection, showed that the immature neural cells were the main target of viral replication (Mutnal at al. 2011; Tsutsui at al. 2002). Moreover, studies performed on human NSPCs cultures, demonstrated the greatest susceptibility to HCMV of these cells, in which the effects of viral replication depend on their differentiation state (Hernández-Salinas at al. 2015; Li at al. 2009; Odeberg at al. 2006).In order to explore these findings, the differentiation stage of HCMV-infected neural/neuronal cells was investigated. In our small population, the main neural/neuronal marker expressed by HCMV-positive cells was DCX (94\%), the antigen identifying the neural progenitor cells with a determined lineage (as neuroblasts). Nestin, that is the 
marker detecting the neural cells in an early stage of differentiation, was found in the $63.3 \%$ of HCMVpositive cells, while no HCMV-infected cell resulted positive for NeuN, the antigen expressed by mature neurons. These findings showed that the HCMV-infected cells were mainly NSPCs, confirming the preferential tropism of HCMV for immature and proliferating cells of neuronal lineage. On the other hand, the total absence of HCMV-infected cells expressing NeuN, could be explained by previous human cell culture studies, which showed that mature neurons are refractory to HCMV replication (Cheeran at al. 2009). The HCMV-positive cells that did not express neural/neuronal markers, were probably cells different from those of neuronal lineage. This is in agreement with literature, which reports the ability of HCMV to infect different type of cells in the brain (Gabrielli et al. 2012). Different hypothesis could explain the high proportion of HCMV-positive cells expressing DCX. The first is that it could reflect the diffuse expression of this marker in all brain regions at $21 \mathrm{WG}$, as observed in both control cases and published data. Secondly, it could also speculate that the massive DCX expression among the HCMV-positive cells may be due to a preferential viral replication in neuronal precursor cells rather than in neural stem cells. Finally, the high HCMV-positive cells expressing DCX could be due to an altered ability of infected neuronal progenitor cells to differentiate into mature neurons. The total absence of HCMV-positive cells expressing NeuN, in the cases studied, may be aligned with the latter hypothesis. Studies performed on human cell cultures demonstrated that the HCMV infection in NSPCs led to either the inhibition or delay of differentiation in these cells (Cheeran at al. 2009; Hernández-Salinasat al. 2015; Rahimi-Balaei at al. 2018). The detection of HCMV-infected cells expressing nestin in all brain regions, also in areas where this marker was not present at $21 \mathrm{WG}$, may suggest that HCMV infection could interfere with neuronal differentiation. In control cases, NeuN is mostly expressed in the cortex and weakly in the white matter. On the other hand, NeuN cortical expression in the only fetus with severe brain damage was almost absent, but preserved in fetuses with moderate/mild injury. NeuN immunohistochemistry can individuate signs of neuronal suffering;in fact immunoreactivity has been reported to decrease under several pathologic conditions such as fetal hypoxia and maternal smoking (Lavezzi et al. 2013).

The presence of HCMV-infected cells in the pathways of neuronal migration, may suggest that these cells could retain their ability to migrate, although may be aberrant, as reported by Cheeran et al (2009). Moreover, because HCMV-infected cells were found in all subventricular zone, including periventricular region and ganglionic eminence, where immature cells depart for radially and tangentially neuronal migration, respectively, both migration modes could be affected. In conclusion, although in a small number of CCMV infected fetuses, this study suggests a preferential viral tropism for NSPCs, that may lose or delay their capacity to differentiate, while may retain their ability to migrate. All these findings may result in reduced proliferation of immature neural cells, cellular signaling alterations, cell death, and aberrant neuronal migration. The latter may lead to abnormal brain development, such as intracranial calcification, polymicrogyria, lissencephaly, and other consequences frequently detected in cCMV infection. The pathological findings detected in this study showed brain features at 21 weeks of gestation and it is difficult to establish the subsequent evolution of the injury. However, the only fetus with severe pathological findings could probably have had a poor outcome, since necrosis, periventricular leukomalacia and polymicrogyria are parenchymal brain lesions associated with permanent neurological sequelae (Krstanovic et al. 2021, Leruez-Ville et al. 2020). 
In light of these results suggesting the direct role of HCMV in the pathogenesis of cCMV-related brain damage, additional features of cerebral injury will have to be investigated in all encephalicregions, such as the effects of the immune responses and the development degree of additional infected cell types involved in the neurogenesis, such as glial cells.

\section{Abbreviations}

HCMV

human cytomegalovirus

cCMV

congenital HCMV

$\mathrm{IHC}$

immunohistochemistry

DCX

doublecortin

NeuN

neuronal nuclei

hDNA

humanDNA

NSPCs

neural stem/progenitor cells

CNS

central nervous system

MCMV

murine cytomegalovirus

HSV-1

herpes simplex virus-1

WG

week of gestation

LLOQ

lower limit of quantification

$\mathrm{AF}$

amniotic fluid.

\section{Declarations}

\section{Funding}

Not applicable.Theauthors did not receive support from any organization for the submitted work.

Disclosure of potential conflicts of interest/competing interests 
The authors declare that they have no conflicts of interest/competing interests.

\section{Availability of data and material}

Data and materials are available with conditions for access, if the request is reasonable and justified.

\section{Code availability}

Not applicable.

\section{Author's contributions}

Piccirilli Giulia, Gabrielli Liliana, Bonasoni Maria Paola and Lazzarotto Tiziana designed the study. Bonasoni Maria Paola, Salfi Nunzio Cosimo Mario and Santini Donatella performer histological analysis. Piccirilli Giulia, Gabrielli Liliana, Chiereghin Angela, Turello Gabriele, Borgatti Eva Caterina, Simonazzi Giuliana, Felici Silvia and Leone Marta did data collection. Piccirilli Giulia, Gabrielli Liliana, Bonasoni Maria Paola and Turello Gabriele wrote the paper and assisted in generation of Figures. Lazzarotto Tiziana provided critical reading of the manuscript. All authors participated in the data interpretation and approved the final version of the manuscript.

\section{Ethical approval (research involving human participants)}

All procedures performed in studies involving human participants were in accordance with the ethical standards of the institutional and/or national research committee and with the 1964 Helsinki declaration and its later amendments or comparable ethical standards.

The study was approved by the Ethical Committee of IRCCS S. Orsola Polyclinic, University Hospital, Bologna, Italy (approval numbers: 14/2017/U/tess and 8/2010/0/Sper).

\section{Informed consent}

Informed consent was obtained from all individual participants included in the study.

\section{Consent for publication}

Not applicable.

\section{Acknowledgments}

This work is based on the PhD thesis of Dr. Giulia Piccirilli that was deposited in the theses institutional archive of University of Bologna under an embargo period. We would like to thank Lucy Scioscia for editing the English text.

\section{References}


1. Boppana SB, Ross SA, Fowler KB (2013) Congenital cytomegalovirus infection: clinical outcome. Clin Infect Dis 57(Suppl 4):S178-181

2. Cheeran MC, Lokensgard JR, Schleiss MR (2009) Neuropathogenesis of congenital cytomegalovirus infection: disease mechanisms and prospects for intervention. Clin Microbiol Rev 22(1):99-126

3. Chen X, Cho DB, Yang PC (2010) Double staining immunohistochemistry. N Am J Med Sci 2(5):241245

4. Chen Z, Zhong D, Li G (2019) The role of microglia in viral encephalitis: a review. J Neuroinflammation 16:6. doi:10.1186/s12974-019-1443-2)

5. Cotran RS, Pober JS (1989) Effects of cytokines on vascular endothelium: their role in vascular and immune injury. Kidney Int 35(4):969-975

6. Damasio AR, Van Hoesen GW (1985) The limbic system and the localisation of herpes simplex encephalitis. J NeurolNeurosurg Psychiatry 48(4):297-301

7. Fernández-Arjona MDM, Grondona JM, Granados-Durán P, Fernández-Llebrez P, López-Ávalos MD (2017) Microglia morphological categorization in a rat model of neuroinflammation by hierarchical cluster and principal components analysis. Front Cell Neurosci 11:235. doi:10.3389/fncel.2017.00235)

8. Fink KR, Thapa MM, Ishak GE, Pruthi S (2010) Neuroimaging of pediatric central nervous system cytomegalovirus infection. Radiographics 30(7):1779-1796

9. Fowler KB, Stagno S, Pass RF (2003) Maternal immunity and prevention of congenital cytomegalovirus infection. JAMA 289:1008-1011

10. Gabrielli L, Bonasoni MP, Chiereghin A, Piccirilli G, Borgatti EC, Simonazzi G, Salfi NCM, Tamagnini I, Lazzarotto T (2020) Pathophysiology of Hyperechogenic Bowel in Congenitally Human Cytomegalovirus Infected Fetuses. Microorganisms 22(5):779

11. Gabrielli L, Bonasoni MP, Chiereghin A, Piccirilli G, Santini D, Pavia C, Turello G, Squarzoni D, Lazzarotto T (2017) Salivary glands and human congenital cytomegalovirus infection: What happens in early fetal life? J Med Virol 89(2):318-323

12. Gabrielli L, Bonasoni MP, Foschini MP, Silini EM, Spinillo A, Revello MG, Chiereghin A, Piccirilli G, Petrisli E, Turello G, Simonazzi G, Gibertoni D, Lazzarotto T (2019) Histological Analysis of Term Placentas from Hyperimmune Globulin-Treated and Untreated Mothers with Primary Cytomegalovirus Infection. Fetal Diagn Ther 45(2):111-117

13. Gabrielli L, Bonasoni MP, Lazzarotto T, Lega S, Santini D, Foschini MP, Guerra B, Baccolini F, Piccirilli G, Chiereghin A, Petrisli E, Gardini G, Lanari M, Landini MP (2009) Histological findings in fetuses congenitally infected by cytomegalovirus. J Clin Virol 46:S16-21

14. Gabrielli L, Bonasoni MP, Santini D, Piccirilli G, Chiereghin A, Guerra B, Landini MP, Capretti MG, Lanari M, Lazzarotto T (2013) Human fetalinnerearinvolvement in congenitalcytomegalovirusinfection. Acta NeuropatholCommun 1:63. doi:10.1186/2051-5960-1-63)

15. Gabrielli L, Bonasoni MP, Santini D, Piccirilli G, Chiereghin A, Petrisli E, Dolcetti R, Guerra B, Piccioli M, Lanari M, Landini MP, Lazzarotto T (2012) Congenitalcytomegalovirusinfection: patterns of fetal 
brain damage. ClinMicrobiollnfect 18(10):E419-427

16. Gaytant MA, Steegers EA, Semmekrot BA, Merkus HM, Galama JM (2002) Congenital cytomegalovirus infection: review of the epidemiology and outcome. ObstetGynecolSurv 57:245-256

17. Guerra B, Simonazzi G, Puccetti C, Lanari M, Farina A, Lazzarotto T, Rizzo N (2008) Ultrasoundprediction of symptomaticcongenitalcytomegalovirusinfection. Am J ObstetGynecol 198:380e1-380e7. doi: 10.1016/j.ajog.2007.09.052)

18. Harris SA, Harris EA (2018) Molecular mechanisms for herpes simplex virus type 1 pathogenesis in Alzheimer's disease. Front Aging Neurosci 10:48. doi:10.3389/fnagi.2018.00048)

19. Hernández-Salinas A, Noyola DE, Jiménez-Capdeville ME, Martínez-Serrano A, Castillo CG (2015) Effects of cytomegalovirus infection in human neural precursor cells depend on their differentiation state. J Neurovirol 21(4):346-357

20. Ho WS, van den Pol AN (2007) Bystander attenuation of neuronal and astrocyte intercellular communication by murine cytomegalovirus infection of glia. J Virol 81(13):7286-7292

21. Kenneson A, Cannon MJ (2007) Review and meta-analysis of the epidemiology of congenital cytomegalovirus (CMV) infection. Rev Med Virol 17:253-257

22. Kopp SJ, Banisadr G, Glajch K, Maurer UE, Grünewald K, Miller RJ, Osten P, Spear PG (2009) Infection of neurons and encephalitis after intracranial inoculation of herpes simplex virus requires the entry receptor nectin-1. Proc Natl Acad Sci USA 106(42):17916-17920

23. Krstanović F, Britt WJ, Jonjić S, Brizić I (2021) Cytomegalovirus Infection and Inflammation in Developing Brain. Viruses 13(6):1078

24. Kwak M, Yum MS, Yeh HR, Kim HJ, Ko TS (2018) Brain magnetic resonance imaging findings of congenital cytomegalovirus infection as a prognostic factor for neurological outcome. 83:14-18

25. Langford TD, Letendre SL, Marcotte TD, Ellis RJ, McCutchan JA, Grant I, Mallory ME, Hansen LA, Archibald S, Jernigan T, Masliah E, HNRC Group (2002) Severe, demyelinating leukoencephalopathy in AIDS patients on antiretroviral therapy. AIDS 16:1019-1029

26. Lathe R, Haas JG (2017) Distribution of cellular HSV-1 receptor expression in human brain. J Neurovirol 23(3):376-384

27. Lavezzi AM, Corna MF, Matturri L (2013) Neuronal nuclear antigen (NeuN): a useful marker of neuronal immaturity in sudden unexplained perinatal death. J Neurol Sci 329(1-2):45-50

28. Lazzarotto T, Gabrielli L, Guerra B, Cervi F, Piccirilli G, Simonazzi G, Chiereghin A, Bellini F, Landini MP (2014) Diagnosis and prognosis of congenital CMV infection: a case report and review of the literature. Scand J Clin Lab Invest Suppl 244:34-40

29. Leruez-Ville M, Foulon I, Pass R, Ville Y (2020) Cytomegalovirus infection during pregnancy: state of the science. Am J ObstetGynecol 223(3):330-349

30. Levitz RE (1998) Herpes simplex encephalitis: a review. Heart Lung 27:209-212

31. Li L, Wang B, Li P, Bai ZQ, Wang HT, Song XX, Ding SY (2009) Human cytomegalovirus infection inhibits the differentiation of human hippocampus neural precursor cells into astrocytes. VirologicaSinica 24(6):552 
32. Lokensgard JR, Cheeran MC, Gekker G, Hu S, Chao CC, Peterson PK (1999) Human cytomegalovirus replication and modulation of apoptosis in astrocytes. J Hum Virol 2:91-101

33. Ludlow M, Kortekaas J, Herden C, Hoffmann B, Tappe D, Trebst C, Griffin DE, Brindle HE, Solomon T, Brown AS, van Riel D, Wolthers KC, Pajkrt D, Wohlsein P, Martina BEE, Baumgärtner W, Verjans GM, Osterhaus ADME (2016) Neurotropic virus infections as the cause of immediate and delayed neuropathology. Acta Neuropathol 131(2):159-184. doi: 10.1007/s00401-015-1511-3)

34. Mack I, Burckhardt MA, Heininger U, Prüfer F, Schulzke S, Wellmann S (2017) Symptomatic Congenital Cytomegalovirus Infection in Children of Seropositive Women. Front Pediatr 5:134. doi: 10.3389/fped.2017.00134)

35. Malinger G, Lev D, Zahalka N, Ben Aroia Z, Watemberg N, Kidron D, Sira LB, Lerman-Sagie T (2003) Fetal cytomegalovirus infection of the brain: the spectrum of sonographic findings. AJNR Am J Neuroradiol 24(1):28-32

36. Mook-Kanamori B, van de Beek D, Wijdicks EF (2009) Herpes simplex encephalitis with normal initial cerebrospinal fluid examination. J Am Geriatr Soc 57:1514-1515

37. Mutnal MB, Cheeran MC, Hu S, Lokensgard JR (2011) Murine cytomegalovirus infection of neural stem cells alters neurogenesis in the developing brain. PLoS ONE 6(1):e16211. doi:10.1371/journal.pone.0016211)

38. Nebuloni M, Pellegrinelli A, Ferri A, Tosoni A, Bonetto S, Zerbi P, Boldorini R, Vago L, Costanzi G (2000) Etiology of microglial nodules in brains of patients with acquired immunodeficiency syndrome. $J$ Neurovirol 6:46-50

39. Odeberg J, Wolmer N, Falci S, Westgren M, Seiger A, Söderberg-Nauclér C (2006) Human Cytomegalovirus inhibits neuronal differentiation and induces apoptosis in human neural precursor cells. J Virol 80(18):8929-8939

40. Pass RF, Arav-Boger R (2018) Maternal and fetal cytomegalovirus infection: diagnosis, management, and prevention. F1000Res 7:255. doi: 10.12688/f1000research.12517.1)

41. Perlman JM, Argyle C (1992) Lethal cytomegalovirus infection in preterm infants: clinical, radiological, and neuropathological findings. Ann Neurol 31(1):64-68

42. Potel C, Kaelin K, Danglot L, Triller A, Vannier C, Rozenberg F (2003) Herpes simplex virus type 1 glycoprotein B sorting in hippocampal neurons. J Gen Virol 84:2613-2624

43. Rahimi-Balaei M, Bergen $\mathrm{H}$, Kong J, Marzban H (2018) Neuronal Migration During Development of the Cerebellum. Front Cell Neurosci 12:484. doi:10.3389/fncel.2018.00484)

44. Rawlinson WD, Boppana SB, Fowler KB, Kimberlin DW, Lazzarotto T, Alain S, Daly K, Doutré S, Gibson L, Giles ML, Greenlee J, Hamilton ST, Harrison GJ, Hui L, Jones CA, Palasanthiran P, Schleiss MR, Shand AW, van Zuylen WJ (2017) Congenital cytomegalovirus infection in pregnancy and the neonate: consensus recommendations for prevention, diagnosis, and therapy. Lancet Infect Dis 17(6):e177-188

45. Robillard KN, Lee KM, Chiu KB, MacLean AG (2016) Glial cell morphological and density changes through the lifespan of rhesus macaques. Brain Behavlmmun 55:60-69 
46. Rock RB, Gekker G, Hu S, Sheng WS, Cheeran M, Lokensgard JR, Peterson PK (2004) Role of microglia in central nervous system infections. Clin Microbiol Rev 17(4):942-964

47. Schleiss MR (2008) Congenital cytomegalovirus infection: update on management strategies. Curr Treat Options Neurol 10(3):186-192

48. TröscherAR,Wimmer I, Quemada-Garrido L, Köck U, GessI D, Verberk SGS, Martin B, Lassmann H, Bien CG, Bauer J (2019) Microglial nodules provide the environment for pathogenic $T$ cells in human encephalitis. Acta Neuropathol 137(4):619-635

49. Tsutsui $\mathrm{Y}$, Kawasaki $\mathrm{H}$, Kosugi I (2002) Reactivation of latent cytomegalovirus infection in mouse brain cells detected after transfer to brain slice cultures. J Virol 76(14):7247-7254

50. Tsutsui Y, Kosugi I, Kawasaki H (2005) Neuropathogenesis in cytomegalovirus infection: indication of the mechanisms using mouse models. Rev Med Virol 15(5):327-345

51. Yin X, Li L, Zhang X, Yang Y, Chai Y, Han X, Feng Z (2013) Development of neural stem cells at different sites of fetus brain of different gestational age. Int J Clin Exp Pathol 6(12):2757-2764

52. Yoon JY, Danielson B, Mathis D, Karamchandani J, Munoz DG (2017) Cytomegalovirus in the human dentate gyrus and its impact on neural progenitor cells: report of two cases. Clin Neuropathol 36(5):240-245

53. Zhang XY, Fang F (2019) Congenital human cytomegalovirus infection and neurologic diseases in newborns. Chin Med J 132(17):2109-2118

\section{Figures}

\section{Figure 1}

Histological findings in brain injury. Diffuse microglial activation (increased number of rod-shaped cells, arrows) [a], astrocytosis (cell with clear nuclei, named Alzheimer type II, arrow) [b] and vascular changes (plump endothelial cell protruding into the vassal lumen cell, arrow) [c] detected in all brain regions (hematoxylin-eosin staining $40 \mathrm{HPF}$, Scale bar $50 \mu \mathrm{m}$ ). Microglial nodules (arrow) [d] were occasional ( $<3 /$ brain region) and multiple in brain with mild and moderate/severe damage, respectively (hematoxylineosin staining, $100 \mathrm{HPF}$, Scale bar $50 \mu \mathrm{m}$ ). Necrosis in cortical layer III (between the arrows) and polymicrogyria [e] were found in the brain with severe injury (hematoxylin-eosin staining, 4 HPF, Scale bar $500 \mu \mathrm{m})$.

\section{Figure 2}

HCMV-DNA levels in the brain.Distribution of tissue viral load in different brain regions. 


\section{Figure 3}

HCMV-infected cells in temporal lobe.HCMV-infected cells (brown-stained cells) from subventricular zone (filled arrow) to cortex (dashed arrow). These positive cells, located along the migration pathway, show slender extension typical of radial glia (hematoxylin-eosin staining, $4 \mathrm{HPF}$, Scale bar $500 \mu \mathrm{m}$ ).

\section{Figure 4}

HCMV-positive cells in the brain. Distribution of mean HCMV-infected cell values in different brain areas (total subventricular zone refers to both periventricular areas and ganglionic eminence)

\section{Figure 5}

HCMV-antigen and neural/neuronal cell marker expression. HCMV-positive cells expressing HCMVantigens and nestin [a,b], DCX [c] or NeuN [d] are identified by both brown and red staining (filled arrow); uninfected cells expressing only nestin [a], DCX [c] or NeuN [d] are identified by red staining (dashed arrow); double immunohistochemistry, $40 \mathrm{HPF}$, Scale bar $50 \mu \mathrm{m}$.

\section{Figure 6}

NeuN expression and brain damage. Expression of NeuN (red cells) in cortical area of temporal lobe in case with severe (a) moderate (b) and mild (c) encephalic damage (double immunohistochemistry, 4 HPF, Scale bar $500 \mu \mathrm{m})$ 


\section{Figure 7}

Expression of neural/neuronal cell markers in control cases. Expression of nestin in subventricular zone [a], white matter [b] and cortical area [c]; expression of DCX in cortical area [d] hippocampus [e] subventricular zone [f] and white matter [g]; expression of NeuN in cortical area [h] and subventricular zone [i] (immunohistochemistry, $4 \mathrm{HPF}$, Scale bar $500 \mu \mathrm{m}$ ).

\section{Supplementary Files}

This is a list of supplementary files associated with this preprint. Click to download.

- graphicalabstract.pdf 